\title{
Controversial cancer drug wins local approval in Italy
}

[ROME] The southern Italian region of Puglia announced last week that it is prepared to provide the expensive drug somatostatin free to cancer patients, even though the drug has no proven efficacy in most cancers and is not on the national list of reimbursable drugs.

The decision represents the latest move in a four-month battle between the conventional medical community and the supporters of an unconventional approach to cancer therapy claimed to be based on stimulating the body's self-healing properties. The situation echoes the dispute over the controversial drug laetrile in the United States in the 1970s.

The so-called Di Bella approach was developed by an 85-year-old physician, Luigi Di Bella, from Modena near Bologna. He argues that established approaches to therapy directed at cancerous cells are fundamentally flawed, and that cures can be achieved only by stimulating the body's selfhealing properties.

The battle over Di Bella's claims has all the ingredients of classic Italian high drama, and has come to a head in a direct conflict between the judiciary and the state. Several judges have ordered that the drug, which can cost up to US $\$ 6,500$ a month, should be made available to individual patients free of charge because of the guarantee in the Italian constitution to protect the health of individuals.

But Italy's minister of health, Rosa Bindi, insists that "the judiciary cannot decide on therapy", and has resisted an emotional campaign led by relatives of cancer patients and doctors who support Di Bella's unconventional therapy.

Di Bella tailors a cocktail of drugs and vitamins to individual patients, but the mix always includes somatostatin. He claims to have cured thousands of patients in this way over the past 30 years, although he has never published details of his results.

Although somatostatin is expensive, many patients who have not been cured by conventional chemotherapy have turned enthusiastically to the Di Bella method. Socalled Di Bellists have organized frequent demonstrations to demand state support for the treatment, and many have taken their claims to court.

The story hit the headlines last month after a judge in Lecce, Puglia, ordered the state to pay for his plaintiffs' treatment. Several other local judges followed, and the media fanned the flames, portraying conventional medicine as a conspiracy condemning poorer cancer patients to die.
Before Christmas, Bindi ordered Di Bella to submit his files on patients to the health ministry by this week. But he has been reluctant to do so, contending that the medical establishment will reject his treatment method out of hand.

Di Bella's supporters have also reacted with hostility to an offer by Bindi to assemble an international panel of independent experts to help to assess the Di Bella files and help to decide whether there is a strong enough scientific basis to warrant a clinical trial.

A spokesman for the Italian Association for the Assistance of Neoplastic Patients says it has no faith in the fairness of an international committee. It is demanding that the ministry create a series of Di Bella cancer treatment centres where the results of the treatment could be monitored.

Parliament's social affairs committee meets this week to discuss what it describes as "the conflict of competence between judges and the governmental scientific institutions". But the problem is so sensitive that it will not be resolved simply by reference to law and logic, according to Giuseppe Benegiano, director of the Higher Institute of Public Health in Rome.

"The issue would be totally emotional anywhere because it involves the dying," says Benegiano. "And since Italy is a country famous for its emotion, the effect gets multiplied." Given the "explosive mixture of issues," he says, the only solution may be to conduct a full clinical trial, even though available data do not provide strong support for such a move.

In the US case, laetrile extracted from apricot stones was hailed as a miracle cure for cancer in the 1970s. Despite the absence of scientific evidence of anticancer activity, several states defied the Food and Drug Administration and allowed the drug to be prescribed. Public pressure finally forced the agency to conduct trials, which proved negative.

Umberto Veronesi, scientific director of the European Institute of Oncology in Milan, admits to watching the Italian drama with resignation verging on despair: "We've come to expect this sort of claim [for a miracle cure] every two or three years. But eventually they get forgotten." Alison Abbott

\section{Fire damages Germany's Einstein tower}

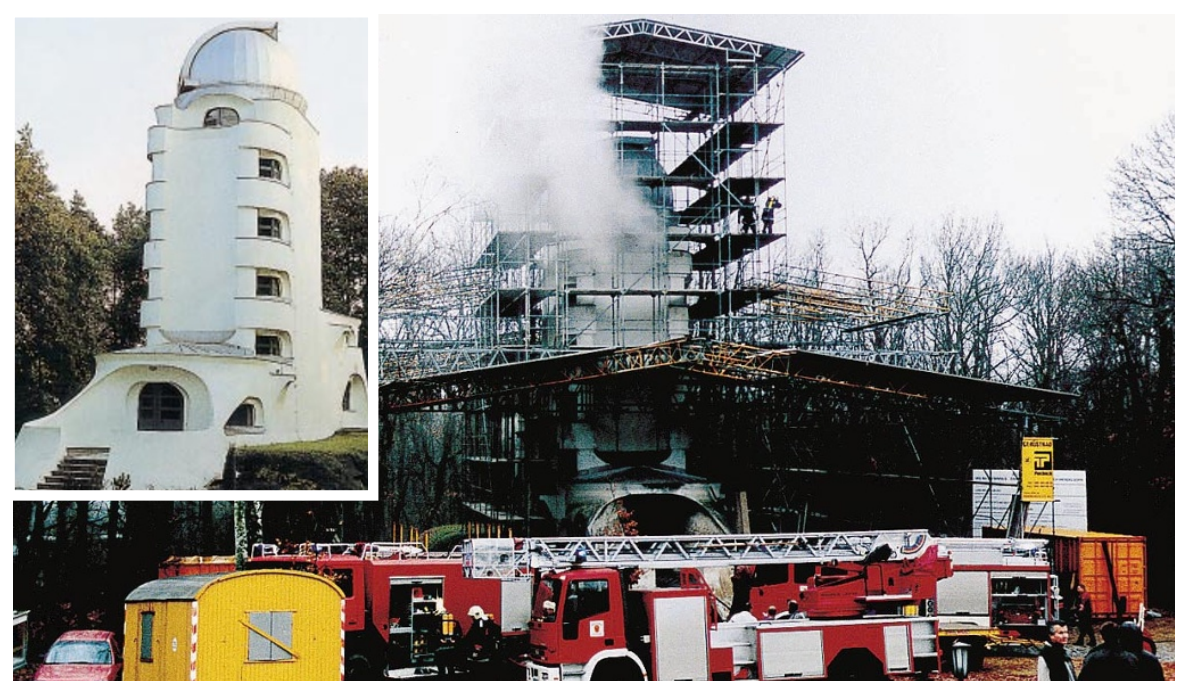

[BERLIN] Germany's best-known piece of scientific architecture, the Einstein tower, was damaged by fire last week after a spark ignited solvent used in renovation work.

The building's scientific instruments remain intact, however, as they had been removed last autumn in preparation for the overhaul, which was needed following decades of neglect during communist rule in East Germany.

The tower (inset), which is in Potsdam near Berlin, was built in the expressionist style in the early 1920s by the renowned architect Erich Mendelsohn as a solar observatory to test predictions of Einstein's general theory of relativity. It remains an important reference in the history of European architecture, and has continued to play a scientific role. For example, it made solar observations in parallel with the European Space Agency's space-based solar observatory SOHO, which was launched in December 1995.

Günther Hasinger, a director of the Astrophysical Institute in Potsdam which owns the tower, says that damage to the tower's infrastructure will be repaired by the end of the year. 